\title{
Brazilian SMEs of the Industrial Health Complex: Export Performance from the Resource-Based View
}

\author{
Luiz G M Mury ${ }^{1}$ \\ ${ }^{1} \mathrm{PhD}$ in International Strategic Studies at Federal University of RS, Porto Alegre, Brazil \\ Correspondence: Luiz G M Mury, PhD in International Strategic Studies at Federal University of RS, Porto Alegre, \\ Brazil.
}

Received: November 4, 2016 Accepted: November 16, 2016 Online Published: November 17, 2016

doi:10.11114/bms.v2i4.1990 URL: http://dx.doi.org/10.11114/bms.v2i4.1990

\begin{abstract}
The present paper analyzes the export performance of the Brazilian industrial health complex based on an exploratory research on small and medium-sized companies that integrate the project known as Brazilian Health Devices - BHD. The paper begins by approaching the Resource-based View theory, a theoretical framework that sees resources as key to superior firm performance. It then follows with a characterization of the health industry in Brazil, and concludes with an analysis of conducted interviews with companies that integrate with the project. Outcome of research made aware that many of the BHD members limit their international operations within the range of the collective operations of the project, thus, they do not develop any differentiated resources that could lead them to a sustainable competitive advantage in the foreign market.
\end{abstract}

Keywords: resource-based view, health industry, exports

\section{Introduction}

Despite the large Brazilian health market, many small and medium-sized domestic manufacturers from the medical-industrial complex have expanded their activities abroad. The search for new markets, in a collective way, takes place mainly through a project called Brazilian Health Devices - BHD (Note 2), implemented by ABIMO Brazilian Association of Industries of Medical, Dental, Hospital and Laboratory Equipment (Note 3) in partnership with Apex-Brazil - Brazilian Trade and Investment Promotion Agency (Note 4). To promote the exports among the members of this project, many different actions are carried out: training courses, business intelligence reports, trade missions, participation in overseas fairs and support towards internationalization. The project was launched in 2002, comprising nowadays over 165 export companies with international sales growing $260 \%$ until 2014 (BHD, 2015). These results, however, are not homogeneous; while some companies have experienced significant growth in their exports, others remained on the same level (Note 5). On one hand, the stability of the exported value indicates economic resilience (international sales remained about the same, even after the 2008 global economic crises and the extended period of a local exchange rate appreciation). On the other hand, there is a question to be asked: what strategies did the outperforming companies take that differentiated them from the less successful participants? In order to answer this question it is necessary, first, to access the academic literature about business strategies and then apply its theory to analyze the interviews conducted with the members of the BHD project.

This paper is divided into six sections: after this introduction, section 2 is dedicated to briefly review the three leading perspectives regarding business performance, mainly focusing on the resource-based view theory. Section 3 presents a description of the Brazilian industrial health complex, while section 4 is reserved to the field research and the analysis of the export performance among the sectoral project members of Brazilian Health Devices. Section 5 presents the findings, and finally, section 6 concludes the paper.

\section{Theoretical Framework}

\subsection{Background}

According to Peng (2009), the strategic management theory has three leading perspectives regarding business performance: (i) the industry-based view, (ii) the institution-based view and (iii) the resource-based view. The first approach, the industry-based view, has emerged in the economy segment called Industrial Organization (Note 6) 
through one of its main contributions: the Structure-Conduct-Performance (SCP) model (Note 7), which states that the structure of the market of an industry (Note 8) influences the company's economic conduct or strategy, which in turn affects its performance. The purpose of the Industrial Organization is to regulate industries that have earnings above the average, which is in opposition to the companies' interests of maximizing their profits. For this reason, Porter (1989) deepens the SCP approach, developing a strategic business model composed by 5 forces. This Model, known as Porter's diamond, states that the competitiveness of a given industry is shaped by the intense rivalry between competitors, threat of replacement products, threat of new competitors, power of buyers and the bargaining power of suppliers. The second approach, the institution-based view, questions the reasons why subsidiaries of a multinational or even similar companies located in different countries or regions have different strategies / behaviors. Furthermore, not only the institutions, but also culture and ethics strongly influence the conduct through societies' formal rules (regulations) and informal rules (norms and conducts); therefore, the performance of companies from different locations. According to this view, it is not rationality, but the instincts and habits that drive the economic behavior (SANDRONI, 2004). The third approach, resource-based view, argues that differences in performance between companies are caused essentially by each company's resources and capacity. This approach will be further discussed in the fourth section, when the international performance of some Brazilian health devices manufactures will be analyzed under this perspective.

Considering a SWOT matrix (Note 9), the industry-based view focuses its analysis on the external threats and opportunities, while the resource-based view concentrates on the company's internal strengths and weaknesses. Finally, the institution-based view includes the study of the structure, rules and behavior of institutions - companies, cartel laws, unions, the State and its organizations, among others. Peng (2009, p.17) says that even though there is much discussion on this matter among the different schools of thought, the determinants of a company's performance are probably a combination of these three approaches. Nevertheless, given that only companies were the object of this study, the analysis presented in the fourth section is restricted to the resource-based view. To include the other approaches: industry-based view and institution-based view, it would be necessary to investigate the market (buyers, suppliers, etc.) and institutions not only in Brazil, but also in the countries that regularly acquire health products "made in Brazil".

The next subsection will present the roots of the Resource-based view, its main concepts and, according to this theory, what explains outstanding and sustainable business performance.

\subsection{Resource-based View Theory (RBV)}

A new theory is usually developed by researchers based on previous approaches. In the specific case of the Resource-Based View (RBV), the theory is connected at least to four sources of inspiration (Note 10): (i) studies on distinctive competences; (ii) Ricardo's economic theory of rent; (iii) Penrose's studies, and (iv) Antitrust Acts. In the book "The Theory of the Growth of the Firm" (PENROSE, 2007), first published in 1959, Edith Penrose argues that companies should be understood first of all as administrative organizations that unify and manage the activities of many individuals and groups. Second, they should be taken as a set of productive resources which are managed by administrative decisions. Therefore, the growth of a firm is restricted to the discovering of opportunities as a result of its controlled set of productive resources and, moreover, to the administrative organization used in order to manage these resources. Regarding the Antitrust acts, economists have stated, based on of the SCP paradigm, that companies have the tendency to present a better performance and achieve higher profits when operating in a market other than one of perfect competition (Note 11). However, Demsetz (1973) suggested that a higher performance could be a result of an atypical insight of a company's manager and of the competitors' inability to identify the same opportunities or copy them. Thus, the company's positive outcome would derive from a higher internal ability and not from the market structure.

The resource-based approach had fallen into academic oblivion before it was revived in 1984 by Wernerfelt and Rumelt (BARNEY and CLARK, 2009), (FREILING, 2009). Wernerfelt has sought to develop a theory to explain that performance differences among companies is about the internal resources they control, and not about external factors to the company, as developed by Porter. He named this approach as vision because it presented a distinct look to the same question - competitive performance, but from a different perspective. Rumelt (Note 12), on the other hand, has developed a strategical theory to explain the reasons why some companies focus on generating economic income in a much more efficient way than others. This author also defined companies as a set of productive resources and proposed that isolation mechanisms hinder the power to imitate such resources, which, in turn, would ensure a higher income generation. From then on, several papers followed this line of thought, developing the view that the business performance is linked to the company's resources.

According to the RBV theory, organizations are composed by a set of resources and capabilities, and some of them cannot be easily acquired or imitated. As these especial resources begin to be a factor of income generation, they can become a source of sustainable and competitive advantage. In this case, there are two premises: the internal resources 
and capabilities provide the basic direction to find out the long-term strategy and are the primary sources of the company's profit.

In order to deepen the understanding, it is necessary to first define the concept of resources, which are divided by PENG (2009) into ( $i$ ) tangible: resources that are observable and easily quantified (such as financial, material, technological or organizational resources) and (ii) intangible: resources that are not easily observed or that are difficult to quantify (such as the human capital, the capability of innovation, reputation, among others). Besides this division between tangible and intangible resources, the RBV lists four essential features that resources must have in order to become a source of sustainable and competitive advantage:

(i) Value: Resources that add value to an organization, enabling it to possibly develop a competitive advantage;

(ii) Rarity: Resources that are simultaneously valuable and rare have the potential to provide a temporary advantage to the organization;

(iii) Imitability: Resources that add value and are scarce at the same time may become a source of competitive advantage as long as the competitors are not able to imitate them;

(iv) Organization: Resources that are valuable, rare and difficult to imitate would also require a proper use and management to become a source of sustainable and competitive advantage to the company.

The VRIO framework is provided in schematic form in Table 1. It consists of a methodology to analyze the resources and capabilities that could lead an organization to have a sustainable and competitive advantage.

Table 1. VRIO structure: Possible features to an organization's resources

\begin{tabular}{|c|c|c|c|c|c|}
\hline Valuable? & Rare? & $\begin{array}{l}\text { Difficult to } \\
\text { imitate? }\end{array}$ & $\begin{array}{l}\text { Appropriately } \\
\text { applied? }\end{array}$ & $\begin{array}{l}\text { Competitive } \\
\text { implication }\end{array}$ & $\begin{array}{l}\text { The company's } \\
\text { performance }\end{array}$ \\
\hline No & - & - & No & $\begin{array}{l}\text { Competitive } \\
\text { disadvantage }\end{array}$ & Below average \\
\hline Yes & No & - & Yes & Competitive equality & On average \\
\hline Yes & Yes & No & Yes & $\begin{array}{l}\text { Temporary competitive } \\
\text { advantage }\end{array}$ & Above average \\
\hline Yes & Yes & Yes & Yes & $\begin{array}{l}\text { Sustainable and } \\
\text { competitive advantage }\end{array}$ & $\begin{array}{l}\text { Consistently } \\
\text { above average }\end{array}$ \\
\hline
\end{tabular}

Source: (PENG, 2009, p.72)

The resources that have these four features enable the organizations to have a higher performance than their competitors in the same industry. Therefore, the Resource-based View assumes that the key to success through the development of a strategy is to understand the mechanisms through which a competitive advantage sustains overtime (GRANT, 1991).

In section 4 it will be analyzed the resources owned by some Brazilian exporters of the Brazilian Health Devices project that have lead them to an outstanding performance in comparison to other members of the same project.

\section{Characterization of the Brazilian Health Equipment Industry}

The health equipment industry covers a whole range of products and technologies that go from consumables goods (e.g. syringe) to devices equipped with nanotechnology or remote surveillance. This industry, also known as MHDE Medical, Hospital and Dental Equipment - is known for being strongly innovative and an integrator of technologies, such as fine chemical, microelectronics and precision mechanics. At a global level, there are more than 27,000 companies in that sector employing about 1 million people. In 2009 its global revenues were estimated in U\$ 289 billion, and taking into consideration the annual average growth of $7 \%$, it is expected to reach U $\$ 487$ billion by the end of 2016 (Note 13). The competition in the health industry is strongly characterized by product differentiation through increasingly more advanced technologies, which makes the R\&D investments mandatory to the maintenance or expansion of the companies' market-share (PIERONI et al., 2010). Besides the R\&D investments, the companies invest in quality and certifications not only to meet the requirements of governmental politics, but to overcome technical barriers to exportation.

The first devices of the health sector were produced in Brazil due to the Brazilian politics of import substitution in the $50 \mathrm{~s}$ and $60 \mathrm{~s}$ and to an initiative from immigrants (Note 14). Acting under protectionist measures, such as the national-similar law from 1969 , the industry has developed more complex devices and met about $73 \%$ of the internal demand by 1974 (ABIMO, 2007). However, the market reserve discouraged investments in new technologies, and in the 1990s economic opening ended the process of import substitution and local industry's protection through the 
reduction of import rates (ABDI, 2008). As a consequence of that, the purchase of foreign products has increased considerably, increasing the competitive environment for the national manufacturers. On one hand, the increased competition resulted in the elimination of some national production lines, like radiology equipment, artificial cardiac pacemakers and complex laboratory equipment. On the other hand, some companies have improved their productivity through the access to more technological advanced inputs. Today, the Brazilian health devices industry is mostly composed by small and medium-sized companies with low to intermediate technological level (PIERONI et al., 2010), employing sixty thousand workers divided spread amongst 500 companies, which achieved a turnover of more than US\$ 2,5 billion in 2013 (Note 15).

In accordance with the existing regulations and applications (ABDI, 2008) the Brazilian sector of health devices is segmented in 6 branches: Dentistry (equipment, consumption material and devices), Laboratory (equipment, chemical reagents and consumption products), Radiology (devices, accessories and consumption material) Medical and Hospital Equipment (non-electrical furniture, medical electrical equipment, surgical instruments, physiotherapy equipment and hotel business) and Consumables (hypodermics, textiles, adhesives and others).

Restricted to Latin America until 2005, Brazilian exported goods are currently present in the Arabic and African markets, in Europe and in the United States, bypassing the number of 120 countries. The BHD project members have exported US\$ 122 million in 2014 and intend to achieve the amount of US\$ 139 million in 2016 (Note 16). Table 2 demonstrates the Brazilian exports and imports between 2010 and 2014 segmented between the six mentioned branches:

Table 2. Brazilian trade balance of the health sector between 2010 and 2014

\begin{tabular}{|c|c|c|c|c|c|}
\hline \multicolumn{6}{|l|}{ Exports } \\
\hline & 2010 (Uss) & 2011 (Uss) & 2012 (USS) & 2013 (Uss) & 2014 (USS) \\
\hline Dentistry & $84,457,550.00$ & $86,204,246.00$ & $122,191,821.00$ & $116,022,801.00$ & $117,621,897.00$ \\
\hline Laboratory & $55,836,250.00$ & $63,248,961.00$ & $71,021,573.00$ & $36,527,448.00$ & $84,480,535.00$ \\
\hline Radiology & $25,220,705.00$ & $24,055,634.00$ & $22,352,548.00$ & $25,632,551.00$ & $27,567,442.00$ \\
\hline Implants & $103,576,045.00$ & $122,772,448.00$ & $126,411,194.00$ & $132,683,409.00$ & $135,930,256.00$ \\
\hline Consumables & $316,709,958.00$ & $339,210,266.00$ & $349,450,466.00$ & $350,241,262.00$ & $363,773,753.00$ \\
\hline Total & $633,056,620.00$ & $707,069,862.00$ & $771,153,858.00$ & $737,720,653.00$ & $795,088,775.00$ \\
\hline Laboratory & $883,758,278.00$ & $1,035,863,834.00$ & $1,036,688,044.00$ & $1,103,756,281.00$ & $1,050,598,523.00$ \\
\hline Radiology & $681,398,469.00$ & $717,854,348.00$ & $666,349,066.00$ & $710,230,268.00$ & $652,840,292.00$ \\
\hline Medical and Hospital Equip. & $726,193,308.00$ & $684,126,631.00$ & $877,433,158.00$ & $990,108,458.00$ & $1,012,638,651.00$ \\
\hline Implants & $550,485,548.00$ & $628,646,121.00$ & $723,758,823.00$ & $720,671,780.00$ & $727,663,858.00$ \\
\hline Consumables & $765,969,032.00$ & $919,934,582.00$ & $1,093,699,468.00$ & $1,246,210,706.00$ & $1,217,217,216.00$ \\
\hline Total & $3,667,075,340.00$ & $4,066,341,544.00$ & $4,506,633,593.00$ & $4,901,148,354.00$ & $4,775,626,992.00$ \\
\hline
\end{tabular}

Source: Brazilian health devices, 2015

\section{Fieldwork}

\subsection{Methodology}

The structuring of a research consists, as per Malhotra (2012), in the following steps: (i) definition of the research (Note 17) problem; (ii) development of approaching techniques; (iii) elaboration of the research's conception; (iv) fieldwork; (v) data organization and analysis (vi) presentation of research reports. The present paper intends to investigate the reasons behind the outstanding performance of a few Brazilian manufacturers when it comes to exporting health related devices. In order to accomplish that, a qualitative research was performed following a three-stage script.

In the first stage, a brief revision about the Resource-based View theory has been presented, along with a characterization of the Brazilian industry of health-related devices.

In the second stage a qualitative survey was conducted with 23 Brazilian exhibitors of the Brazilian Health Devices project during the trade show MEDICA 2015. The interviews during the exhibition allowed to meet personally with leaders of some of the major exporters in the sector, who in Brazil are located in 15 different cities. According to 
Malhotra (2012), convenience sampling is a non-probabilistic technique that seeks to get a sample of convenient elements, and its units are mostly selected by the interviewer himself. Following, public export data from the interviewed companies have been raised by value range between 2001 and 2015, and it was found that three of them (Note 18) grew its foreign sales quite more than the others, as shown in Annex 1. The interviews approached essentially three topics: (i) The internationalization process: the goal was to identify what had motivated the companies to operate internationally: market diversification, brand internationalization, or the need to fulfill the demand of an importer? (ii) International operating model: establishment of an international branch office, adequacy of products to the target markets, registry of trademarks, prospecting new customers, and (iii) Barriers to increase exports. In the businessman's point of view, what would be the impediments to expand international sales?

Finally, in the third stage, companies that presented an outstanding growth in comparison to the other participants in the BHD project were questioned, in the context of the VBR theory, about the internal resources they possess in order to achieve that performance.

\subsection{Results of the Second Stage - the Interviews}

The starting point of the interviews regarded the beginning of companies' exports. Among the 23 respondents, 7 of them affirmed that they began exporting due to external opportunities, such as the establishment of a partnership with an importer during the Hospitalar Fair (Note 19) or as a response to governmental stimulation to export. The remaining companies pointed out various reasons to initiate their international sales: ownership of an innovative device, desire to compare their technology with the rest of the world and prospect to expand businesses and opportunities within prospective markets. The following question, regarding the main markets and the profile of their customers, has indicated that the sales are not restricted to the closer areas and countries, since many manufacturers claimed to have customers in the Middle East, Africa, Eastern Europe and Asia, besides Latin America. On the other hand, the profiled customers are almost exclusively distributors because the companies argue they need to register their products, offer training courses and participate in public bids. When asked about what relevant investments they had been made to increase their exports, companies pointed to more than one alternative as shown in Table 3, highlighting the certification and adaptation of products. Among the 34 answers collected, only one has mentioned the creation of a physical structure abroad as a relevant investment.

Table 3. Interviewed companies: Relevant investments when it comes to exporting

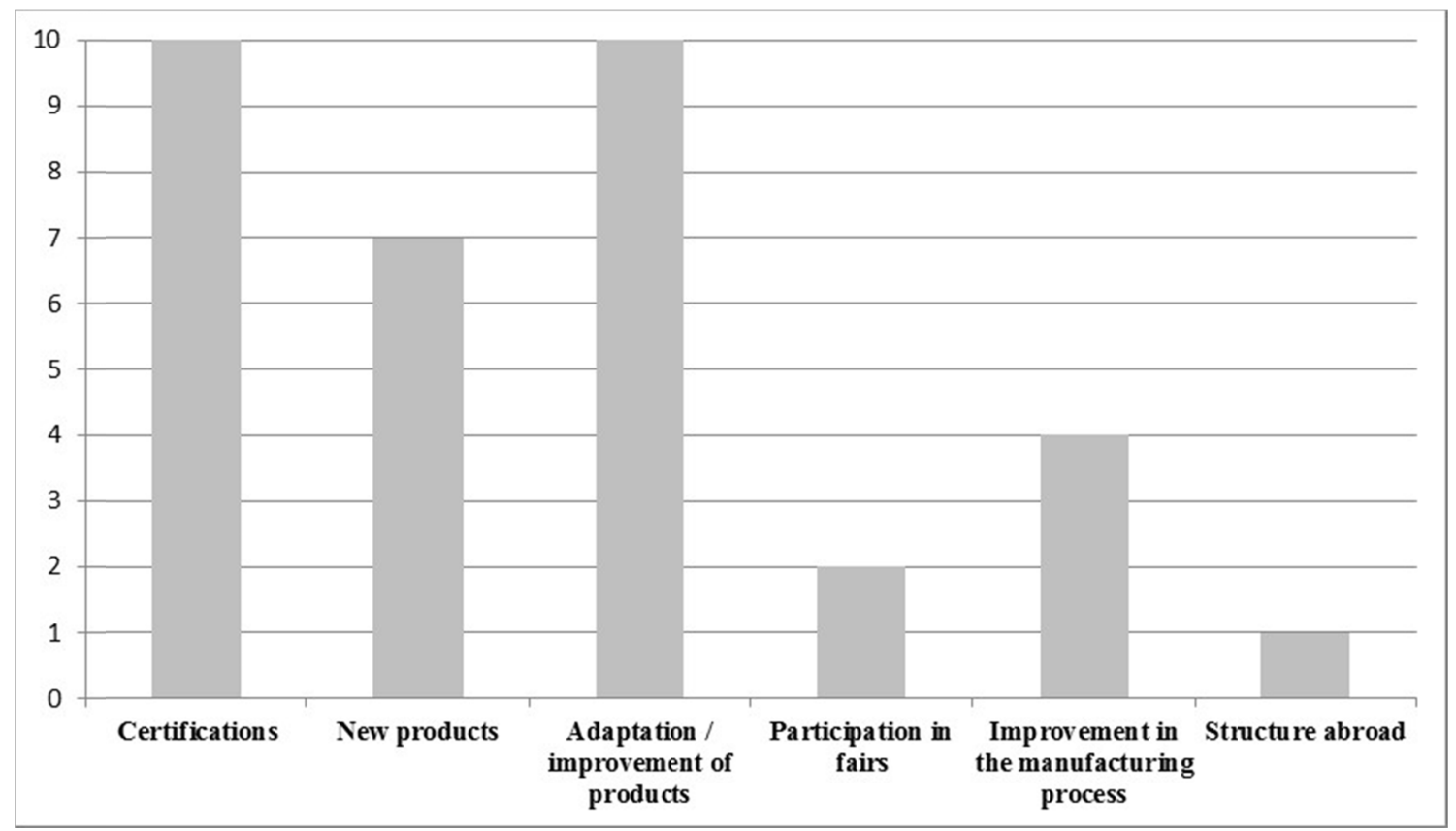

Source: Interviews carried out during the MEDICA 2015 fair

The following question was deliberately an open-ended one (Note 20): what is necessary to expand exports nowadays? It was answered in two ways: external or internal issues. Among the main answers, stating exogenous issues were the so-called "Brazil cost" (Note 21), the reputation of the country (customers do not acknowledge Brazil as a supplier of high technology and quality goods), and national subsidy for international certifications. The main answer with "homework" issues, with 5 citations, was: it is necessary to show presence to the customers. After that, with 2 citations 
each: it is necessary to secure partnerships in the target market and to adapt the products for the target market. It is important to highlight that in order to solve the two previously mentioned issues, it is necessary to gain presence in the target market to be able to identify the right partners and to understand the local demands.

The remaining questions intended to deepen the understanding about the international strategy adopted in the last few years. Following this direction, it was asked about the existence of international projects, brand of the sold products, the international trademark registry, export share in turnover, international events that they participate and how international clients are prospected.

\subsection{Results of the Third Stage: the RBV Approach}

Starting from the public data supplied by MDIC (Note 22) - that classifies the exporters within various ranges during the years of 2001 to 2015 - it was identified that 3 members of the BHD project had gotten a positive and steady evolution in their exports (Annex 1). Assuming that all the participants in the project had the same chances of commercial exposition abroad (fairs, missions, qualification courses, reports about commercial intelligence and governmental support to internationalize), we asked, on the basis of the Resource-based View, about the internal resources these companies think that are linked to their excelling results in comparison to other companies.

The three companies answered the following question: in your opinion, which are the internal resources that your company possesses to reach such a positive evolution in its exports? First company did not point out any differentiated internal resources; the good performance is attributed to the local representatives selected during international trade shows. The second one claimed that the reason for its success is due to its differentiated product, which was conceived as global from the very beginning - meaning that besides several improvements, there would be no need to adapt it for each new prospective market. At last, the third respondent understands that its success is the result of a multifactorial combination of product, presence and teamwork: product for having a consequent value proposition; presence for making it possible to understand the channels of sale in each country where the company operates, and teamwork because it consists of professional specialists - internally and in the target market as well.

\section{Findings}

Considering all collected answers, it is possible to affirm that the companies are in expressively distinct degrees of internationalization. While 14 of them affirmed that they do not have any physical presence abroad nor any cooperation agreements, some claimed to have technician salesmen in distinct continents, joint ventures to develop specific markets, or even factories in the United States and India. This proactive behavior in the international market also reflects on export volume, which ranges from $1 \%$ to $50 \%$ among the interviewed companies, as well as on the brand of the exported products. Although these are mostly brands that belong to the companies, only three companies claimed to trademark their brands in each country where they operate, and two companies claimed to do so only in few countries.

On one hand, the majority of the companies stated that the customers prospection takes place in missions and trade fairs organized by the sectoral project, Brazilian Health Devices, disclosing the importance of the project for the international performance of the Brazilian health equipment industry. On the other hand, the research indicates that only a few companies have independent commercial strategies that allow them to establish international relations outside the events organized by the project. Thus, a cause and effect relationship is established: the majority of the interviewed companies invest too little time and resources in export efforts; hence, exports have a low representation in their turnover.

Many companies pointed out the relevance of the costs for the necessary adaptations in domestic products to access new markets. To overcome this barrier, they suggest that the State subsidize the process, what could be avoided if the products were conceived and developed for the global market. Another matter taken into consideration was the preferred channel of sales. Despite the fact that a distributor is the best option when it comes to sales, delegating the trademark registry, the certification of products and the commercial networking could turn into a problem if the partnership somehow comes to an end.

Finally, the answers of the two successful companies that claim to possess differentiated resources corroborate the study of Dhanaraj and Beamish (2003), who identified the following sets of resources that influence the strategy and the export performance: technological, organizational, and entrepreneurial resources. The technological resources are responsible for the success of the company that had developed a global and technologically superior product compared to the ones carried out by competitors. In turn, the second company possesses organizational and entrepreneurial resources for developing a multidisciplinary team and, consequently, having a direct and constant presence in the countries where it operates. 


\section{Conclusions}

This paper has analyzed the export performance of the industrial health complex of Brazil through exploratory research with a sample of small and medium-sized companies that are part of the Brazilian Health Devices project. The paper started by approaching the Resource-based View theory, applied to explain the performance difference between the BHD members. Section 3 presented a characterization of the Brazilian health equipment industry and, finally, the interviews were presented and analyzed in section 4. To achieve a well-succeeded international performance, a company should first of all identify and evaluate the internal resources that can lead to a competitive advantage in the future (TIERGARTEN and ALVES, 2008). The primary data-collecting with the BHD members showed that a great part of them restrict international presence to the activities of the sectoral project BHD. Furthermore, although valuable internal resources that are rare, difficult to copy and adequately employed had been observed only in a few companies that participate in the BHD project, they must serve as an example to others in their search for foreign markets, as these resources enabled them to outperform their export results.

\section{References}

ABIMO (2007). -Brazilian Industry Association of Medical and Dental Equipment. History of Abimo and Sinaemo: building health of a country. São Paulo: Abimo.

ABDI (2008). - Brazilian Agency for Industrial Development. 2008. Outlook sector: Medical, hospital and dental equipment. Center for Management and Strategic Studies. -Brasilia: Brazilian Agency for Industrial Development. Available at: http://www.abdi.com.br/Estudo/volume\%207.pdf, access on $20^{\text {th }}$. Dec. 2015.

Barney, J., \& Clark, D. (2007). Resource-Based Theory. Creating and Sustaining Competitive Advantage. New York: Oxford University Press.

BHD - Brazilian Health Devices, (2015). Institutional site. Available at: http://brazilianhealthdevices.com.br/, access on $17^{\text {th }}$ Dec. 2015.

Demsetz, H. (1973). Industry Structure, Market Rivalry and Public Policy, Journal of law and Economics, 16(1), 1-9. https://doi.org/10.1086/466752

Dhanaraj, C., \& Beamish, P. (2003). A Resource-Based Approach to the Study of Export Performance. Journal of Small Business Management, 41(3), 242-261. https://doi.org/10.1111/1540-627X.00080

Freiling, J. (2001). Resource-based View und ökonomische Theorie - Grundlaglagen und Positionierung des Ressourcenansatzes. Wiesbaden: Gabler. https://doi.org/10.1007/978-3-322-85214-4

Grant, R. (1991). The resource-based theory of competitive advantage: implications for strategy formulation. Knowledge and strategy, 33(3), 3-23. https://doi.org/10.2307/41166664

Malhotra, N. K. (2012). Marketing Research: An Applied guidance. 6. ed. Porto Alegre: Bookman.

MDIC- (2016). Ministry of Development, Industry and Foreign Trade. Institutional site. Available at: $\mathrm{http}: / /$ www.mdic.gov.br//sitio/interna/interna.php?area $=5 \& \mathrm{menu}=603$, access on $3^{\text {rd }} \mathrm{Jan}$.

Peng, M. (2009). Global Strategic Management, Cengage Learning, 2nd ed. Canada.

Penrose, E. (2007). Theory of the firm's growth. 1'. Ed. Campinas: Unicamp.

Porter, M. (1989). Competitive Advantage: Creating and Sustaining Superior Performance. Rio de Janeiro: Campus.

Pieroni, J., Reis, C., \& Souza, J. (2010). The industry of medical equipment and supplies, hospital and dentistry: A Bndes's action proposal. Available at:

http://www.bndes.gov.br/SiteBNDES/export/sites/default/bndes_pt/Galerias/Arquivos/conhecimento/bnset/set3105 .pdf, access on $08^{\text {th }}$ Dec. 2015.

Rumelt, R. (1984). Towards a Strategic Theory of the Firm, Competitive Strategic Management, New Jersey: Prentice-Hall, 556-570.

Sandroni, P. (2004). Newest Dictionay of Economy. $14^{\text {th }}$ ed. São Paulo: Best Seller.

Scherer, F., \& Ross, D. (1990). Industrial market structure and economic performance. Princeton.

Tiergarten, M., \& Alves, C. (2008). The Resource Based View as Business Strategy: A Study of the main approaches from a framework of theoretical references. Rev. Universo Administração, 2, 61-74,

Wernerfelt, B. (1984). A Resource-based view of the firm, Strategic Management Journal, 5, 171-180. https://doi.org/10.1002/smj.4250050207 


\section{Notes}

2 - Sector project implemented by ABIMO in partnership with Apex-Brazil with the purpose of encouraging the export of items produced by the health industry. Available on: http://brazilianhealthdevices.com.br/about\#/about/project, accessed on 26. Nov. 2015.

3 - Founded in 1962, ABIMO (Brazilian Association of Industries of Medical, Dental, Hospital and Laboratory Equipment) provides support to the health production chain. Operating through boards and work groups, ABIMO is responsible for all technical, operational and associative aspects of the segment. The association currently represents more than 330 domestic and foreign companies, which are responsible for about $90 \%$ of sales of the Brazilian industry. Available on: http://www.abimo.org.br, accessed on 06. Dec. 2015.

4 - The mission of the Brazilian Trade and Investment Promotion Agency (Apex-Brazil) is to encourage the exports of Brazilian products and services, to promote the internationalization of Brazilian's companies and to attract foreign investments to Brazil. Trough initiatives undertaken in a partnership with sector entities, the Apex-Brazil supports more than 13,000 companies in 80 productive sectors of the Brazilian economy that export to more than 200 different markets. Available on: http://www.apexbrasil.com.br, accessed on 06. Dec. 2015.

5 - According to public statistics available, the initial range of exports is up to US $\$ 1$ million. Source: http://www.mdic.gov.br//sitio/interna/interna.php?area=5\&menu=603, accessed on 08. Feb. 2016.

6 - Industrial organization is concerned with the way in which the productivity activities get coordinated with the goods and services demand through an organization mechanism, such as the free market, and questions how its mechanism variations and imperfections can affect the economy's demands (SCHERER and ROSS, 1990).

7 - Purpose of the SCP model is to study variables that affect the economic performance, allowing the development of theories to describe the connections between those variables and the industry's performance. To further details, see PENG (2009).

8 - Understood here as a group of companies that manufacture similar products (goods and services).

9 - SWOT (Strengths, Weaknesses, Opportunities and Threats).

10 - Barney and Clark (2009).

11 - The antitrust act assumes that the social welfare is maximized when the markets are perfectly competitive, and if companies persistently achieve a higher performance, this result from unethical conduct or acts that aspire to minimize the competition.

12 - The five forces that shape strategy. Available on: http://faculty.bcitbusiness.ca/KevinW/4800/porter79.pdf.

13 - Available on: http://brazilianhealthdevices.com.br/.

14 - ABIMO records indicate that in dental sector the first device industries appeared in the decade of 1920 (PIERONI et al., 2010).

15 - Source: http://brazilianhealthdevices.com.br/.

16 - Source: http://brazilianhealthdevices.com.br/.

17 - A qualitative research is defined as a non-structuralized exploratory research technique, based in small samples that provide insights and understanding of the context of the issue that is being studied (Malhotra, 2012).

18 - Taking confidentiality, as well as the common restrictions that keep people from answering questionnaires into consideration, it was decided that the answers should be presented without authorship identification.

19 - A multi-sector trade fair held yearly in São Paulo, Brazil. Hospitalar main sectors are lab instruments, hospital furniture items, orthopedic tools, pharmacy products, rehabilitation equipment, transportation and logistics systems, emergency equipment, kitchen supplies, domestic healthcare products, IT solutions, linens, medical apparel items, traumatology products and related items.

20 - Objective was to obtain an open expression from the businessmen.

21 - This jargon refers to the high expenses that companies have with taxes, logistic and bureaucracy.

22 - Brazilian Ministry of Development, Industry and Foreign Trade. 
Annex 1 - Exhibitors interviewed during the fair MEDICA 2015-Exports by ranges of millions of US \$ between 2001 and 2015

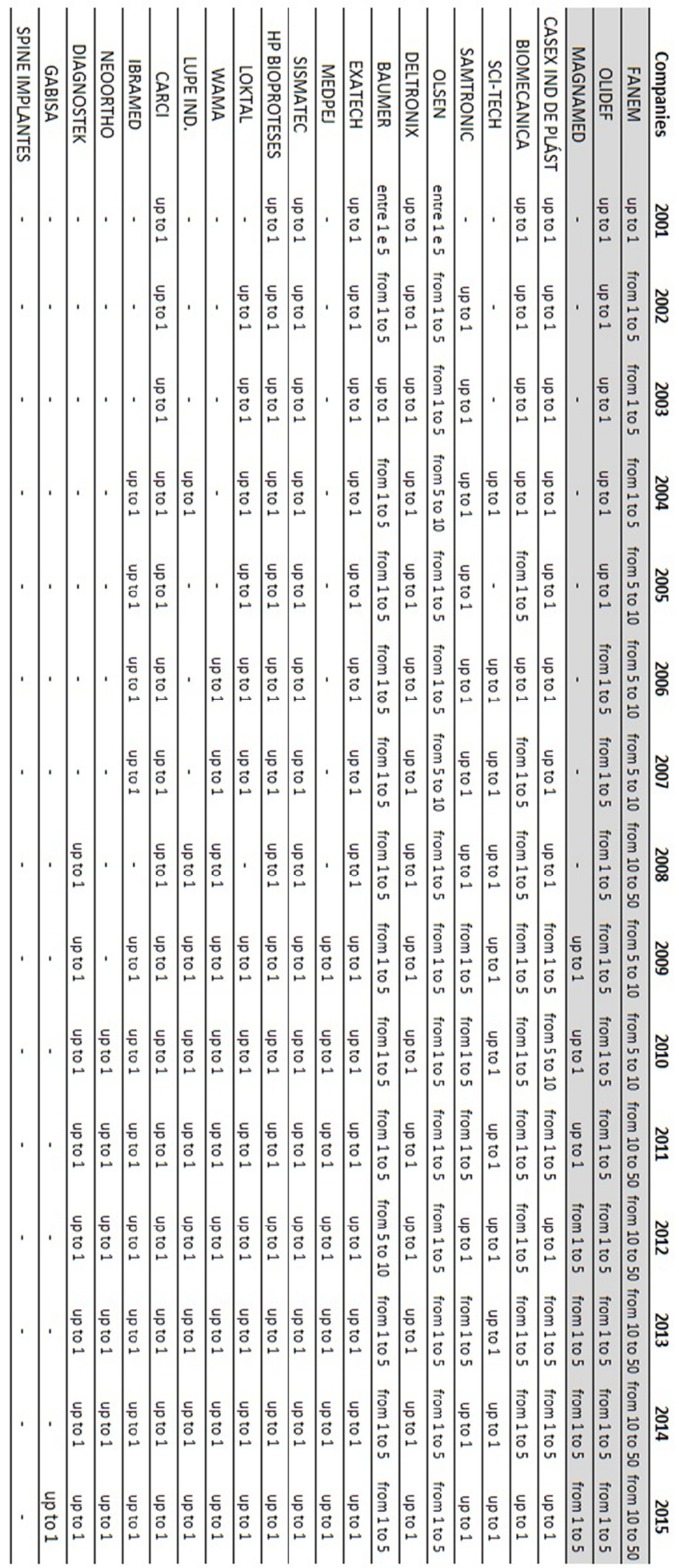

Source: Prepared by the author from MDIC data

\section{$(\mathrm{cc}) \mathrm{EY}$}

This work is licensed under a Creative Commons Attribution 3.0 License. 